CZASOPISMO INŻYNIERII LĄDOWEJ, ŚRODOWISKA I ARCHITEKTURY JOURNAL OF CIVIL ENGINEERING, ENVIRONMENT AND ARCHITECTURE

JCEEA, t. XXXIII, z. 63 (4/16), październik-grudzień 2016, s. 451-466

\author{
Angelika RACZAK ${ }^{1}$ \\ Barbara MARKIEWICZ ${ }^{2}$ \\ Magdalena BATKO ${ }^{3}$
}

\title{
KONTROWERSJE WOKÓŁ PIERZEI ULICY 3 MAJA W RZESZOWIE - ANALIZA WYBRANYCH KAMIENIC
}

\begin{abstract}
Tematem artykułu była ocena wartości historycznej i artystycznej wybranych kamienic usytuowanych przy ulicy 3 Maja w Rzeszowie. Została przedstawiona historia ulicy i zmiana jej znaczenia na przestrzeni ponad 300 lat. Szczegółowo pod względem konstrukcji, kolejnych przebudów i pełnionych funkcji zostały opisane kamienice nr 3, 13 i 20, które zdaniem autorek przeszły największą metamorfozę. Zostały również przeprowadzone badania terenowe i wykonana dokumentacja fotograficzna. Obecny stan omówionych kamienic został poddany ocenie pod względem architektonicznym i kulturowym. Na ich przykładzie odniesiono się do ogólnych tendencji występujących w dzisiejszej polskiej architekturze, które według autorek budzą kontrowersje. Dodatkowo przeprowadzono ankietę na temat zainteresowania ochroną zabytków znajdujących się wzdłuż ulicy 3 Maja wśród studentów i doktorantów Politechniki Rzeszowskiej. Wyniki ankiety przedstawiono w postaci wykresów słupkowych i również omówiono.
\end{abstract}

Słowa kluczowe: ulica 3 Maja w Rzeszowie, architektura Rzeszowa, rzeszowskie kamienice

\section{Cel i przyjęta metodyka}

Celem niniejszej pracy była ocena wartości historycznej i artystycznej wybranych kamienic usytuowanych przy ulicy 3 Maja w Rzeszowie. Szczególną uwagę poświęcono analizie następujących kamienic: nr 3, 13, 20, gdyż według autorek właśnie te kamienice najbardziej zmieniały się pod względem wyglądu i pełnionych funkcji w przeciągu kilkudziesięciu ostatnich lat.

Metodyka badań obejmowała studia historyczne i kwerendy archiwalne miasta Rzeszowa. Przeprowadzono także badania terenowe oraz ankietę wśród stu-

${ }^{1}$ Autor do korespondencji / corresponding author: Angelika Raczak, Politechnika Rzeszowska, al. Powstańców Warszawy 12, 35-959 Rzeszów; angelikaraczak@prz.edu.pl

2 Barbara Markiewicz, Politechnika Rzeszowska, al. Powstańców Warszawy 12, 35-959 Rzeszów; bmarkiewicz@stud.prz.edu.pl

${ }^{3}$ Magdalena Batko, Politechnika Rzeszowska, al. Powstańców Warszawy 12, 35-959 Rzeszów; magdalenabatko89@gmail.com 
dentów i doktorantów odnośnie oceny kamienic ulicy 3 Maja. Wykonano przegląd stanu dotychczasowej dokumentacji oraz inwentaryzację fotograficzną obiektów. Dokonano oceny walorów widokowych, kompozycyjnych i przestrzennych.

\section{Tto historyczne}

Ulica 3 Maja to jedna z najbardziej znanych i reprezentacyjnych ulic na terenie miasta Rzeszowa. Rozpoczyna się od Placu Farnego, gdzie krzyżuje się z ulicą Kościuszki, która prowadzi do Rynku. Dalej krzyżuje się z trzema innymi ulicami, tj. Dymnickiego, Fircowskiego i Alsa oraz jedną z głównych ulic czyli ulicą Jagiellońską. Kończy swój bieg na rozwidleniu ulicy Zamkowej i alei Lubomirskich. Łącznie ulica 3 Maja ma długość ok. 350m. Wzdłuż ulicy usytuowanych jest ok. 20 kamienic, kościół p.w. Świętego Krzyża, I Liceum Ogólnokształcące, a także oddział banku PKO S.A. Na ulicy znajdują się również dwa pomniki, tj. Stanisława Konarskiego oraz Tadeusza Nalepy. Swoją nazwę w przeciągu wieków zmieniała kilkukrotnie. Początki jej istnienia sięgają lat pięćdziesiątych XVII wieku, kiedy to była znana pod nazwą „Pijarska” (Ku Pijarum Scholarum). Kolejne nazwy to: „Popijarska” od 1786 roku, „Pańska” (Herrengasse), od 1828 roku oraz „Paniaga”. Obecną nazwę ulicy nadano w 1891 roku w czasie obchodów 100 rocznicy Konstytucji 3 Maja. W okresie II Wojny Światowej nazywana była „Szeroką” (Breitestraße) [3].

Sięgając czasów najdawniejszych, w miejscu obecnej ulicy przebiegała droga prowadząca na Węgry i do Strzyżowa, która wychodziła z Placu Farnego poza miasto.

W 1354 r. król Kazimierz Wielki nadał prawa miejskie osadzie znajdującej się na terenie dzisiejszego miasta Rzeszowa, jednak nie włączono w nie terenów ulicy 3 Maja. Małe drewniane domki umieszczone były tylko do połowy ulicy, a cała okolica była pokryta bagnami.

Na początku 1600 r. Mikołaj Spytka Ligęza wprowadził znaczące zmiany, między innymi rozpoczął budowę Zamku. Przyczyniło się to do wzrostu znaczenia drogi na południe, która łączyła centrum z nową siedzibą królów.

W połowie XVII w. Rzeszów został przekazany w ręce Lubomirskich i odtąd miasto zaczęło pełnić funkcję artystyczną i kulturową. Około $1654 \mathrm{r}$. Jerzy Sebastian Lubomirski założył kolegium Pijarów, wykorzystując do tego celu budynki powstałe w latach 1642-1646, w których miał znajdować się klasztor sióstr Bernardynek. Rzeszowska szkoła szybko zyskała renomę, a jej wychowankami byli zarówno młodzi szlachcice, jak i mieszczanie.

W XVII wieku wybudowano wieżę farną, zaprojektowaną przez Jana Chrzciciela Belotti'ego, która pełniła funkcję bramy do cmentarza. Do końca XVIII w. nie wprowadzono już żadnych znaczących zmian w zabudowie, gdzie przeważały małe parterowe domki (Rys. 1). 


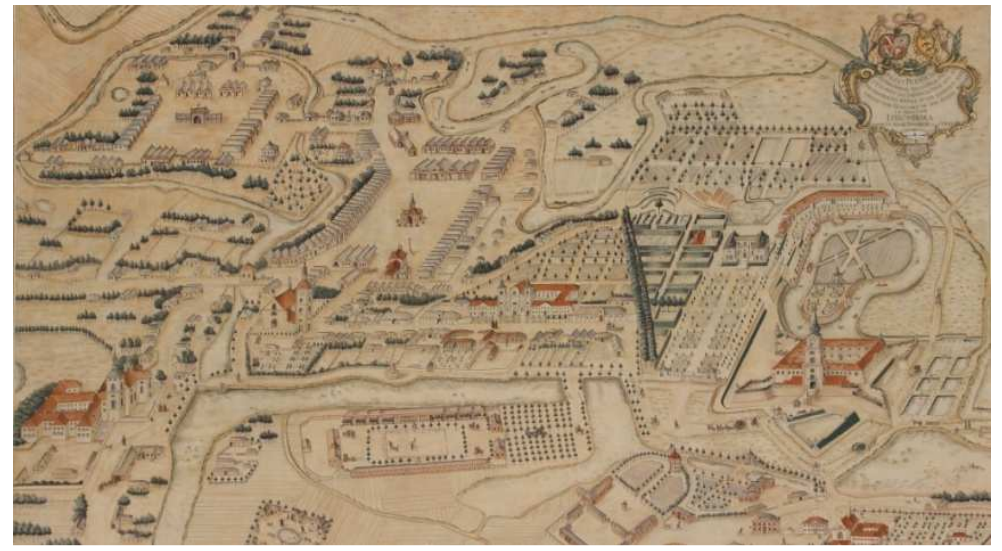

Rys. 1. Widok Rzeszowa z 1762 r. wg planu K. H. Wiedemanna [8]

Fig. 1. View of Rzeszow in 1762 by K.H. Wiedemann [8]

Po I rozbiorze Polski, po wprowadzeniu nowych przepisów przeciwpożarowych, parterowe domy drewniane zastąpiono dwukondygnacyjnymi murowanymi. Na zapleczach pojawiły się oficyny i budynki gospodarcze, które tworzyły podwórko z wejściem od strony ulicy.

Długo ulice Rzeszowa były oświetlane lampami naftowymi, dopiero w 1900 r. pojawiły się lampy gazowe, a 11 lat później - lampy elektryczne. W 1878 r. położono na ulicy nową nawierzchnię i chodniki oraz wybudowano instalację kanalizacyjną.

Okres I wojny światowej przyniósł wiele strat mienia publicznego: szkoły, nawierzchnie i elementy ulic. Z kościoła farnego zdarto nawet miedziany dach. Odbudowa trwała długo i związana była z dużymi kosztami. W okresie międzywojennym mieszkańcy skarżyli się na zanieczyszczenia obecne na głównej ulicy. Do roku 1922 obowiązywał w Rzeszowie ruch lewostronny (Rys. 2).


Rys. 2. Ulica 3 Maja na początku XX w. a) [3]; b) [9]

Fig. 2. 3rd May Street at the beginning of the 20th century a) [3]; b) [9] 
W czasie II wojny światowej lokalne władze dążyły do ujednolicenia wyglądu miasta Rzeszowa, typowego dla niemieckich miast. Wydawane zarządzenia narzucały wygląd fasad, witryn sklepowych i wywieszek. Duże zniszczenia nastąpiły w czasie bitwy o Rzeszów (03.07. - 02.08.1944), kiedy to uszkodzono południową wieżę kościoła Św. Krzyża. Niemcy podpalili kamienice starej poczty i fundacji Alsów oraz zdewastowali kamienice naprzeciwko Banku Polskiego (Rys. 3).

a)

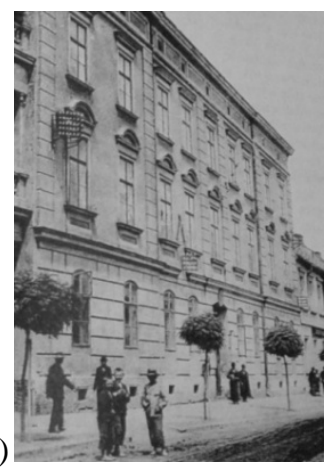

b)

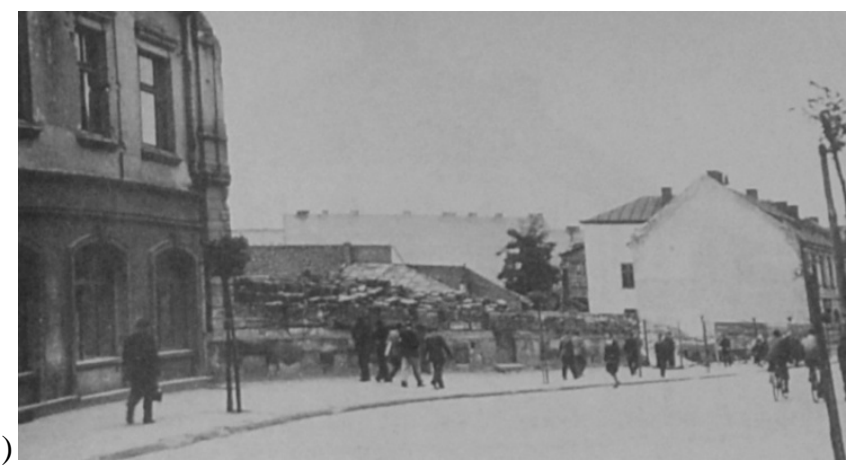

Rys. 3. a) Kamienica starej poczty; b) Gruzy kamienicy po pożarze w 1944 r. [3]

Fig. 3. a) The old postoffice building; b) Debris from the building after the fire in 1944 [3]

Lata 50. i 60. przyniosły kolejne zmiany. Władze zdecydowały się unowocześnić wygląd kamienic i nadać im nowe funkcje. Całkowicie przebudowano budynek dawnej Komunalnej Kasy Oszczędnościowej i otwarto tam „Delikatesy” oraz kawiarnię „Kosmos” (Rys. 4a). W 1956 r. wybudowano najstarsze dziś kino w Rzeszowie - „Zorza” (Rys. 4b).
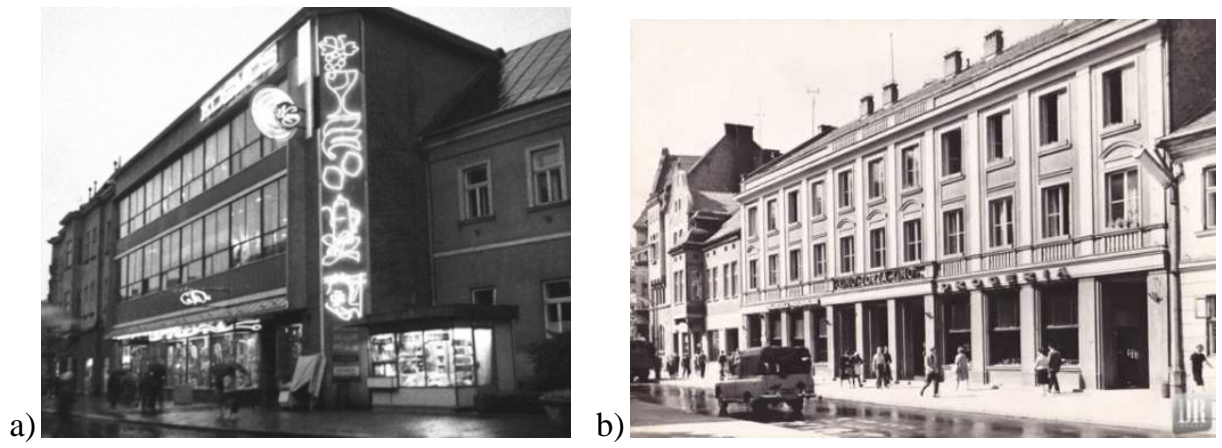

Rys. 4. a) Kawiarnia „Kosmos” [1, 11]; b) Kino „Zorza” [9]

Fig. 4. a) The „Kosmos” (Universe) café [1,11]; b) The „Zorza” (Dawn) cinema [9] 
Lata 70. i 80. są okresem, do którego mieszkańcy Rzeszowa najchętniej wracali pamięcią na różnego rodzaju forach i stronach poświęconych dawnemu wyglądowi miasta. Najczęściej wspominane były sklepy: „Telimena”, „Cepelia”, „Delikatesy”, WPHW- Wojewódzkie Przedsiębiorstwo Handlu Wewnętrznego (kamienica nr 10), restauracje: „Hanka”, Bar Mleczny „Centralny” (3 Maja $6-8)$, „Kosmos”, cukiernia „Wawel” oraz kino „Apollo”[1].

W 1997 r. na ulicy utworzono strefę pieszego ruchu (deptak), niestety pomimo tej funkcji często pojawiały się tam samochody osobowe. $\mathrm{Z}$ powodu lokowania przy ulicy placówek banków i telefonii komórkowych (Rys.5) życie towarzyskie trochę ucichło. Budynki pokryły reklamy, często szpecące. Funkcja salonu miejskiego została przejęta przez rzeszowski Rynek, ze względu na usytuowane tam puby i bary.
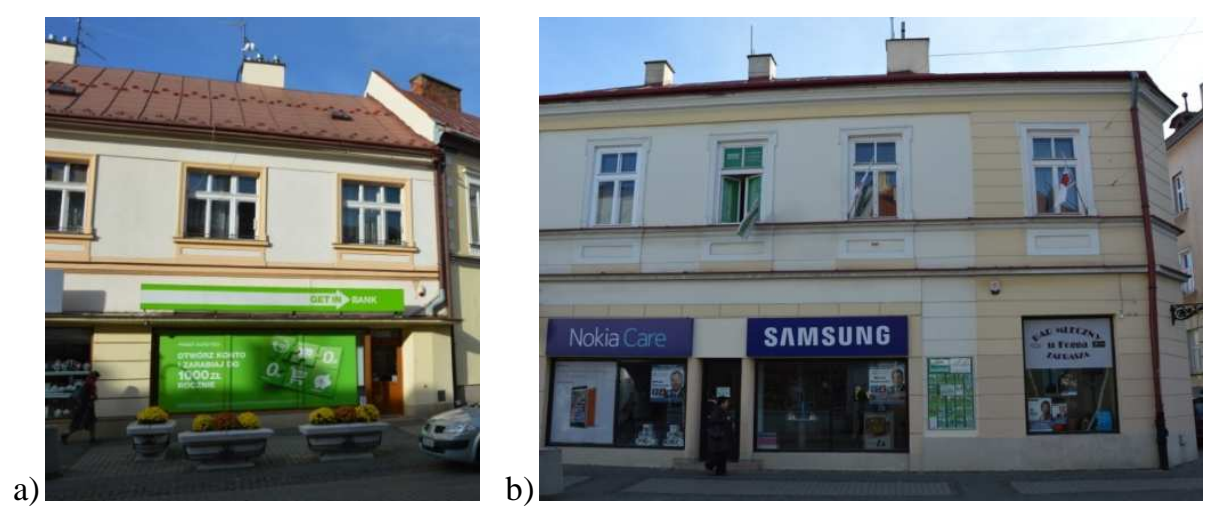

Rys. 5. Reklamy na kamienicach a) $\mathrm{Nr} 2$; b) $\mathrm{Nr} 9$ [6]

Fig. 5. Advertisements on the tenement houses a) No. 2; b) No. 9 [6]

W celu przywrócenia znaczenia ulicy wprowadzono w 2003 roku tzw. Święto Paniagi odbywające się regularnie w rocznicę uchwalenia Konstytucji 3 Maja. Pomysłodawcą tej uroczystości był dziennikarz i publicysta Jerzy Fąfara. Chciał on zatrzymać pędzących Rzeszowian choć na jeden dzień w roku i przypomnieć dawną funkcję ulicy.

\section{Kamienica nr 3}

\subsection{Położenie i konstrukcja}

Kamienica usytuowana jest w zabudowie zwartej wschodniej pierzei ulicy jako druga, idąc od północy. Jest jednopiętrowa. Na parterze znajduje się część usługowa, na piętrze mieszkalna. Rzut budynku kształtem przypomina odwróconą literę C (Rys. 6a). Dwoma końcami styka się on z kamienicą nr 1, tworząc prostokątne podwórze. Jest on nieznacznie wyższy od kamienicy po lewej i nieznacznie niższy od kamienicy po prawej stronie [5]. 


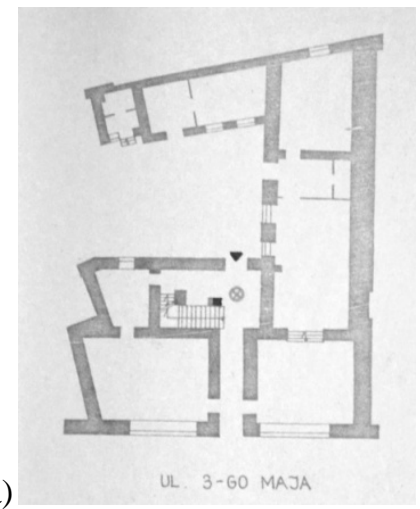

b)

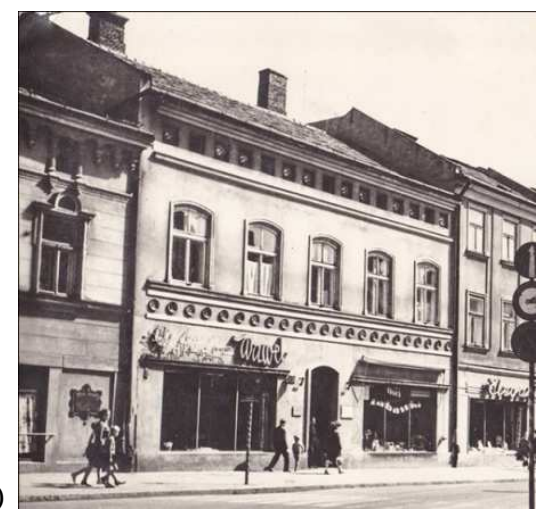

Rys.6. a) Plan [5] i b) elewacja kamienicy nr 3 po remoncie w 1960 r. [9]

Fig. 6. a) The tenement house No. 3 plan [5] and b) facade after renovation in 1960 [9]

Omawiany obiekt wybudowany został w technologii tradycyjnej z murowanymi masywnymi ścianami oraz ceglanymi kolebkowymi stropami. Dach wykonany był jako słupowo-płatwiowo-zastrzałowy pokryty blachodachówką, dwuspadowy w części poddasza użytkowego, a jednospadowy w części strychu. Elewacja natomiast jako dwutraktowa symetryczna, pięcioosiowa $\mathrm{z}$ witrynami na dole i pięcioma jednakowymi otworami okiennymi z nadprożem na piętrze. W ściance kolankowej dostrzec można kasetonowe blendy i okienka strychowe. Przelotowa sień sklepiona kapą czeską prowadzi na podwórko. W drugim trakcie od północy mieści się drewniana klatka schodowa, której podesty są oparte na drewnianych słupach $\mathrm{z}$ dekoracyjną głowicą na piętrze. Na piętrze jest też wyjście na galerię z metalową balustradą [10].

\subsection{Historia}

Według dokumentacji [5] budynek powstał na początku XX w. Pierwotnie kamienica była dwupiętrowa, co można stwierdzić na podstawie starych widokówek. Najstarsze plany budynku pochodzą z 1931 r. i dotyczą adaptacji parteru na sklepy.

W 1960 r. przeprowadzono remont, podczas którego podzielono pomieszczenia mieszkalne na piętrze na mniejsze. Po owym remoncie zachowały się tylko niektóre elementy wnętrz: posadzki taflowe, drzwi płycinowe szklone oraz wspomniane słupy. Układ horyzontalny został podkreślony wtedy przez fryzy z cepeliowskich talerzy ceramicznych (Rys. 6b).

\subsection{Obecnie}

Swój obecny (Rys. 7b) wygląd kamienica zawdzięcza architektowi Grzegorzowi Słapińskiemu. Ostatni remont przeprowadzono w 2012 r. w związku ze zmianą sposobu użytkowania poddasza nieużytkowego na mieszkanie. Od stro- 
a)



b)



Rys. 7. Kamienica nr 3 a) przed remontem [10]; b) po remoncie w 2012 r. [6]

Fig. 7. The tenement house No.3 a) before [10] and b) after renovation in 2012 [6]

ny konstrukcyjnej polegał na zaprojektowaniu dodatkowych podłogowych belek drewnianych oraz częściowej wymianie i wzmocnieniu istniejącej więźby dachowej $\mathrm{w}$ związku $\mathrm{z}$ dodaną warstwą izolacji i sufitem podwieszonym. Ze względu na rysy w ścianie frontowej i posadowienie na gruntach lessopodobnych, które po zawilgoceniu mogą tracić swoją pierwotną nośność, poprawiono szczelność kanalizacji deszczowej by zapobiec dalszemu nierównomiernemu osiadaniu. W celu stwierdzenia dalszego przebiegu procesu osiadania założono plomby szklane.

\subsection{Wnioski}

Ostatni remont kamienicy zdecydowanie poprawił jej stan. Ściany zewnętrzne docieplono, zmieniono kolorystykę na bardziej zdecydowaną, odnowiono zdobienia i skontratowano je $\mathrm{z}$ resztą elewacji. Parter jest teraz boniowany, a zamiast ceramicznych mis wprowadzono prostokątne płyciny, nawiązujące do pobliskich kamienic. Jedynie cokoły zaburzają symetryczny porządek, nawiązując do dwóch różnych budynków. Na dole z prawej strony znajduje się bar sushi, a z lewej ku uciesze mieszkańców nadal mieści się cukiernia. Brakuje jednak talerzy (Rys. 7a), pamiątek po sklepie „Cepelia”, które wyróżniały kamienicę spośrod innych i wisiały tam już ponad 50 lat, mając dla mieszkańców wartość sentymentalną (na podst. wypowiedzi na forach internetowych [9]).

\section{Kamienica nr 13}

\subsection{Lokalizacja i opis obiektu}

Budynek położony jest we wschodniej części szeregu budynków ulicy w zabudowie zwartej, pomiędzy kamienicą nr 11 a I Liceum Ogólnokształcącym. Kamienica jest trzykondygnacyjna na rzucie kształtem przypominającym 
litere „L” $\mathrm{z}$ oficyną w głębi działki [5]. Elewacja frontowa 8-osiowa jest w części II i III kondygnacji prawie w całości pokryta obramowanymi oknami, które na poziomie pierwszego piętra zwieńczone są trójkątnymi tympanonami, nawiązującymi kształtem do konwencji klasycznej. Boczne części budynku występują $\mathrm{z}$ lica elewacji, ale nawiązują wyglądem do środkowej części. Na poziomie boniowanego parteru znajdują się otwory drzwiowe zwieńczone łukowo. Całość nawiązuje do pierwotnego wizerunku tego budynku.

\subsection{Historyczne początki}

Zamysł budowy kamienicy powstał już w 1849 roku, natomiast sama budowa została ukończona dopiero w 1892 roku [5]. Budynek miał stanowić siedzibę Komunalnej Kasy Oszczędności w Rzeszowie. W 1907 roku, po wybudowaniu przez kasę nowego gmachu (dzisiejszy bank PKO BP na 3 Maja 23), piętro kamienicy zajęło Towarzystwo Szkoły Ludowej, a parter - Kawiarnia Europejska, w której organizowano różnego rodzaju imprezy. W wyniku bankructwa kawiarni Towarzystwo Ludowe przejęło parter, gdzie utworzono bibliotekę z czytelnią [2].

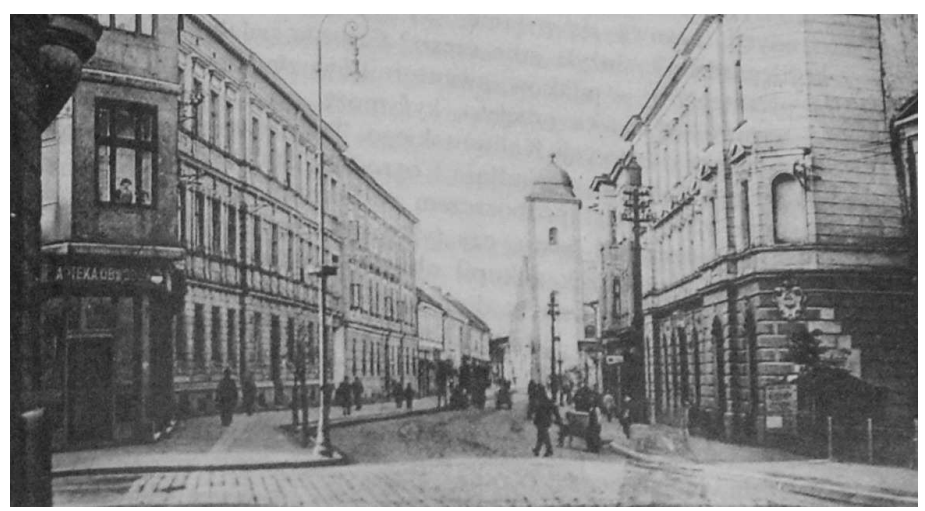

Rys.8. Widok na kamienicę nr 13 (po prawej) z początku XX w. [3]

Fig. 8. View of the tenement house No. 13 (on the right), beginning of the 20th century [3]

Do dzisiaj zachowało się jedynie kilka pocztówek z dawnych czasów obrazujących wygląd ówczesnej kamienicy (Rys. 8). Zarys rzutu budynku pokrywa się z dzisiejszym, ilość kondygnacji również nie uległa zmianie. Ośmioosiowa elewacja frontowa (zryzalitowana w pierwszej i siódmej osi) zrealizowana była zgodnie ze stylem neobarokowym. W ściętym narożniku od południa znajdowała się wnęka z figurą Matki Boskiej [5]. Okna w nadprożu zwieńczone były na każdej kondygnacji w inny sposób: na parterze łukowo, na I-szym piętrze posiadały trójkątne tympanony klasycyzujące, a na II-gim - gzymsy na konsolach. Naroża budynku zdobiły dekoracyjne pilastry [5]. 


\subsection{Kolejne przebudowy}

Po II wojnie światowej budynek przejęły wojska i służby szpiegowskie, później kamienica stała się przejściowo siedzibą II Gimnazjum. Najbardziej znanym użytkownikiem były jednak słynne "Delikatesy" i kawiarnia Kosmos [2]. W 1961 r. przebudowano kamienicę zgodnie z projektem inż. Ptaka - krakowskiego architekta, na potrzeby WSS „Społem” [5]. Po remoncie elewacja frontowa straciła swój neobarokowy wystrój, pokryta była dużymi przeszklonymi pasami okien przebiegającymi na przemian $\mathrm{z}$ pasami podokiennymi (Rys. 9a). Zrezygnowano ze zwieńczeń trójkątnych i innych detali architektonicznych, nadając budynkowi pospolity wygląd. Tak drastyczne zmiany były pomysłem ówczesnych władz, które chciały przystosować kamienicę do nowych funkcji, nadając jej ,nowoczesny” wygląd [1]. To przekształcenie wystroju budynku spowodowało dużą stratę dla wyglądu ulicy, jednak ze względów ekonomicznych przez długi okres nie poczyniono żadnych zmian.

Dopiero nowi właściciele w 2001 roku gruntownie przebudowali kamienicę, chcąc nawiązać do jej pierwotnego wyglądu [7]. Obecnie w kamienicy znanej pod nazwą Galeria Paniaga znajdują się restauracje, salon fryzjerskokosmetyczny oraz placówki eurobanku i biura rachunkowego. Na budynku często widnieją tablice z napisem "lokale do wynajęcia” ze względu na wysokie ceny wynajmu (Rys. 9b).
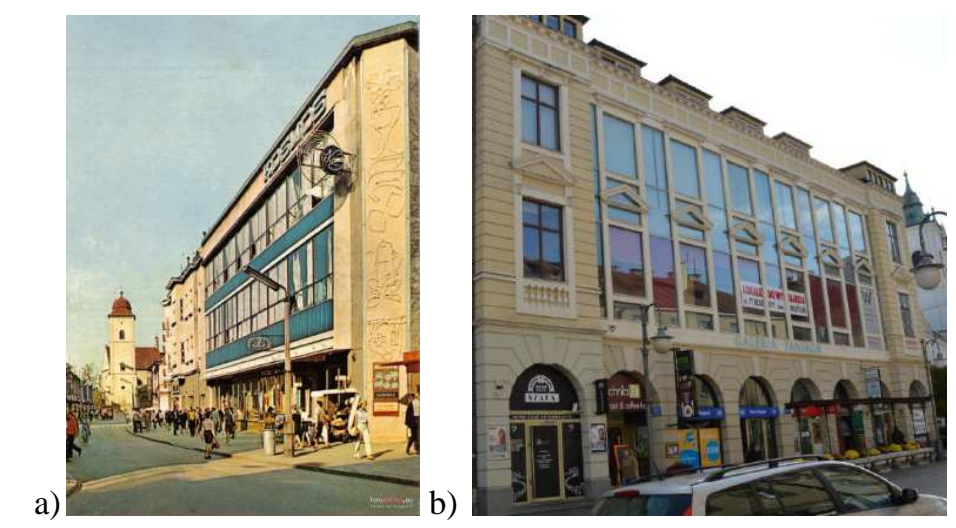

Rys. 9. Widok na kamienicę nr 13 a) w latach 70 [7]; b) w 2014 r. [6]

Fig. 9. The tenement house No. 13 a) in 70's [7]; b) in 2014 [6]

\subsection{Wnioski}

Obecna elewacja w naszej opinii, mimo że nawiązuje do pierwotnego wyglądu, z powodu nagromadzenia zbyt wielu elementów daje wrażenie chaosu. Nowoczesne przeszklenie zwieńczone „klasycyzującymi” tympanonami zrobione zostało bez wyczucia i smaku. Można było stworzyć oryginalne rozwiązanie, 
będące nową wizytówką miasta. Zamiast tego upodobniono ją do otoczenia i sprawiono, że jest niewidzialna. Pomimo, że założenia i chęci były jak najlepsze (unowocześnienie i odświeżenie budynku z uwzględnieniem historii) to granica pastiszu została przekroczona, a uzyskany efekt można określić udawanym zabytkiem. Budynek ten ma jednak nadal potencjał, ze względu na dużą powierzchnię przeszklenia. Niestety nie jesteśmy w stanie go wykorzystać, o czym świadczą puste pomieszczenia kamienicy.

\section{Kamienica nr 20 zwana ,Domem”}

\subsection{Położenie i konstrukcja}

Kamienica ta znajduje się w miejscu zbiegu dwóch ulic: Fircowskiego i 3 Maja. Usytuowany jest naprzeciwko kościoła Pijarów. Z tyłu budynku mieści się niewielkie podwórze. Kamienica murowana z cegły ceramicznej posiada trzy kondygnacje i piwnicę, w której dolne części ścian wykonano z dużych, nieregularnych kamieni. Stropy nad parterem (od ul.3 Maja) i na strychu wykonano jako belkowe o konstrukcji drewnianej, natomiast strop od strony ul. Fircowskiego został wykonany jako stalowo-betonowy. Dachy budynku są dwuspadowe, drewniane, pokryte blachą [5]. Z założenia kamienica była przeznaczona na usługi i mieszkania, co ma zastosowanie do tej pory.

Rzut poziomy budynku składa się z dwóch części: prostokąta usytuowanego równolegle do ulicy 3 Maja oraz węższego, prostopadle dobudowanego od strony ul. Fircowskiego. W obu częściach budynku występuje układ dwutraktowy, posiadający odrębne klatki schodowe (Rys.10).

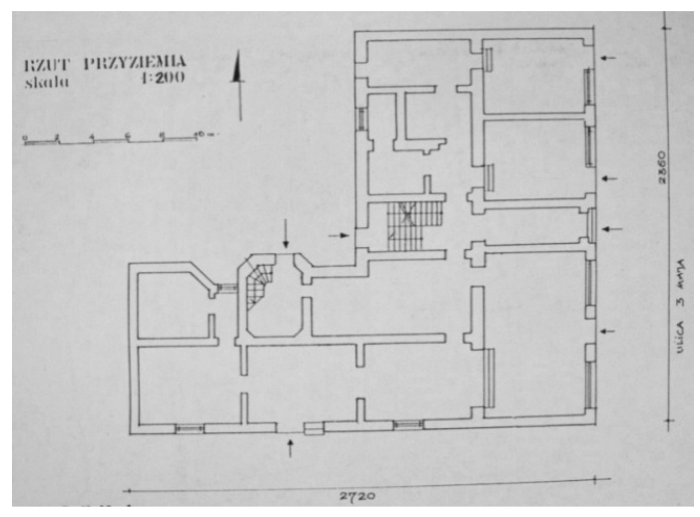

Rys.10. Rzut poziomy kamienicy $\mathrm{nr} 20$ [5]

Fig. 10. The tenement house No. 20 plan [5] 


\subsection{Historia obiektu}

Dokładny okres powstania budynku nie jest znany. Dokumentuje się jego istnienie na widoku Rzeszowa z 1762 r., wykonanego przez K. H. Wiedemanna (Rys.2). Istniał wówczas jako duży, parterowy, dziewięcioosiowy dom o konstrukcji muru pruskiego, pokryty czterospadowym dachem.

Mapa ewidencyjna z 1842 r. przedstawia istnienie kamienicy o wydłużonym rzucie, położonej kalenicowo do ul. 3 Maja z długą i wąską oficyną, usytuowaną oddzielnie. Plany ewidencyjne z 1849 i 1879 r. ponawiają ten sam układ budynku [5].

\subsection{Przebudowa kamienicy}

W 1913 r. architekt Piotr Emilewicz rozpoczął projektowanie i przebudowę kamienicy (Rys.11a), która obejmowała podwyższenie budynku o jedną kondygnację oraz dobudowę części budynku od strony ul.Fircowskiego [5]. Ujednolicono obie elewacje. Frontowa elewacja została wykonana jako symetryczna, dziewięcioosiowa opierająca się na wysokim, gładkim cokole z lastriko, pozbawiona artykulacji pionowej. Na niej znajdowała się wnęka wejściowa. Do pomieszczeń użytkowych na parterze prowadziły osobne wejścia. Stolarka okienna i drzwiowa wykonana została $\mathrm{z}$ drewna dębowego. Parter oddzielony został od wyższych kondygnacji gzymsem kordonowym, pokrytym dachówką. Na wyższej kondygnacji znajdowało się osiem takich samych okien, które łączyły się opaską tynku. Pasy podokienny i nadokienny zostały wykrojone, przyjmując formę wklęsłowypukłą. Na środkowej osi znajdował się balkon z murowaną balustradą z prześwitami. Na najwyższej kondygnacji osie skrajne elewacji zostały zaakcentowane trzyosiowymi, półkolistymi wykuszami, pokrytymi sześciopołaciowymi daszkami. W najwyższej części elewacji frontowej znajdowała się ścianka kolankowa z pięcioma okienkami, zamknięta gzymsem wieńczącym. Elewacja boczna od strony ul. Fircowskiego wykonana jako czteroosiowa nie posiadała wykuszy. Wygląd parteru i okien był jednakowy jak na elewacji frontowej. Przebudowa i nadbudowa została zakończona podczas I wojny światowej w 1915 r. (Rys.11b).

a)



b)



Rys. 11. Widok kamienicy: a) Przed przebudową w 1913 r.[5]; b) Po przebudowie w 1915 r. [9]

Fig. 11. The tenement house: a) before renovation in 1913 [5]; b) after renovation in 1915 [9] 
Przed II wojną światową w budynku znajdowała się cukiernia „Ładosia”. W 1946 r. działka wraz z kamienicą została sprzedana parafii Fara w Rzeszowie. Następnie dom ten został ofiarowany Parafii Św. Krzyża dla bezdomnych, starych księży. Na elewacji frontowej umieszczono napis na tabliczce żeliwnej w kształcie serca: „Błogosławieni miłosierni, albowiem oni dostąpią miłosierdzia”.

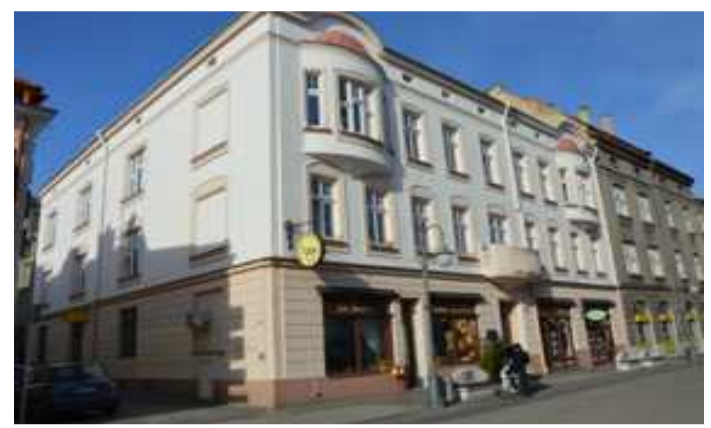

Rys.12. Współczesny widok kamienicy nr 20 [6]

Fig. 12. Current view of the tenement house No. 20 [6]

W 2001 r. kamienica została odremontowana. Dokonano podziału pokoju na pierwszym piętrze na trzy lokale administracyjno-biurowe, poddasze zaś przeznaczono na mieszkania. Wstawiono okna połaciowe, dokonano wymiany stolarki drzwiowej i okiennej. Nad parterem i II piętrem zostały wymienione stropy. Wprowadzono centralne ogrzewanie i ciepłą wodę.

Na podstawie przeprowadzonych badań terenowych możemy stwierdzić, że zachowany stan budynku jest dobry. Zmieniono kolorystykę obiektu, zarówno w elewacji frontowej jak i bocznej. Widoczne dwa okna w elewacji bocznej zostały zasłonięte (Rys.12.).

\subsection{Wnioski}

Obecnie obiekt w bardzo małym stopniu nawiązuje do stanu pierwotnego. $\mathrm{W}$ wyniku przebudowy jego wygląd uległ zmianie. Jednak z naszego punktu widzenia nie było to złe, gdyż architekci dążyli do nawiązania do wyglądu budynku stojącego obok, aby zachować ten sam styl. Naszą wątpliwość budzi jedynie elewacja boczna, gdzie zostały zasłonięte okna, co powoduje nieestetyczny wygląd i wzbudza kontrowersje.

\section{Zrealizowane badania}

Przeprowadzono badania dotyczące zainteresowania ochroną zabytków znajdujących się wzdłuż ulicy 3 Maja w Rzeszowie (Rys.13). Przygotowano 
kwestionariusz wywiadu oparty na pozycji źródłowej [11], który zawierał następujące pytania: 1) Czy jest Pan(i) zadowolony(-na) z ogólnego stanu budynków znajdujących się wzdłuż ulicy 3 Maja?, 2) Jak Pan(-i) sądzi, czy budynki na ulicy 3 Maja są lepszym stanie, takim samym, czy gorszym, w porównaniu z innymi częściami miasta? Jeśli są w lepszym lub gorszym stanie, jaka jest Pana(-ni) zdaniem, tego przyczyna?, 3) Jak Pan(-i) ocenia, czy wśród zabytkowych budowli, znajdujących się wzdłuż ulicy 3 Maja, są takie które utrzymano w dobrym stanie? Jeśli tak, które to obiekty?, 4) Jak Pan(-i) ocenia, czy wśród zabytkowych budowli, znajdujących się wzdłuż ulicy 3 Maja, są takie które uważa Pan (-ni) za będące w złym stanie? Jeśli tak, które to obiekty?, 5) Jak Pan(-ni) sądzi, czy istnieje na ulicy 3 Maja zabytek, który można by uznać za symbol tej ulicy? Jaki to zabytek?, 6) Jak Pan(-ni) uważa, czy robi się dużo, raczej dużo, raczej mało, czy też mało, aby chronić zabytkowe zabudowania wzdłuż ulicy 3 Maja?, 7) Poniżej przedstawiono najczęściej wskazywane potrzeby miasta. Które z nich uważa Pan(i) za najważniejsze w przypadku ulicy 3 Maja? Proszę wybrać 3 odpowiedzi i uszeregować je ważności, gdzie 1 oznacza potrzebę najważniejszą, 2 mniej ważną, 3 najmniej ważną(Rys. 13).

Badaniami objęto 50 osób, w których skład wchodzili studenci i doktoranci różnych kierunków Politechniki Rzeszowskiej. Wiek ankietowanych ustalono na 20-30 lat. Badania wykazały, że respondenci są zainteresowani problematyką ochrony zabytków i że najwięcej spośród badanych jest „raczej zadowolonych” (65\%) (Rys.13a) z wyglądu ulicy i ogólnego stanu budynków.
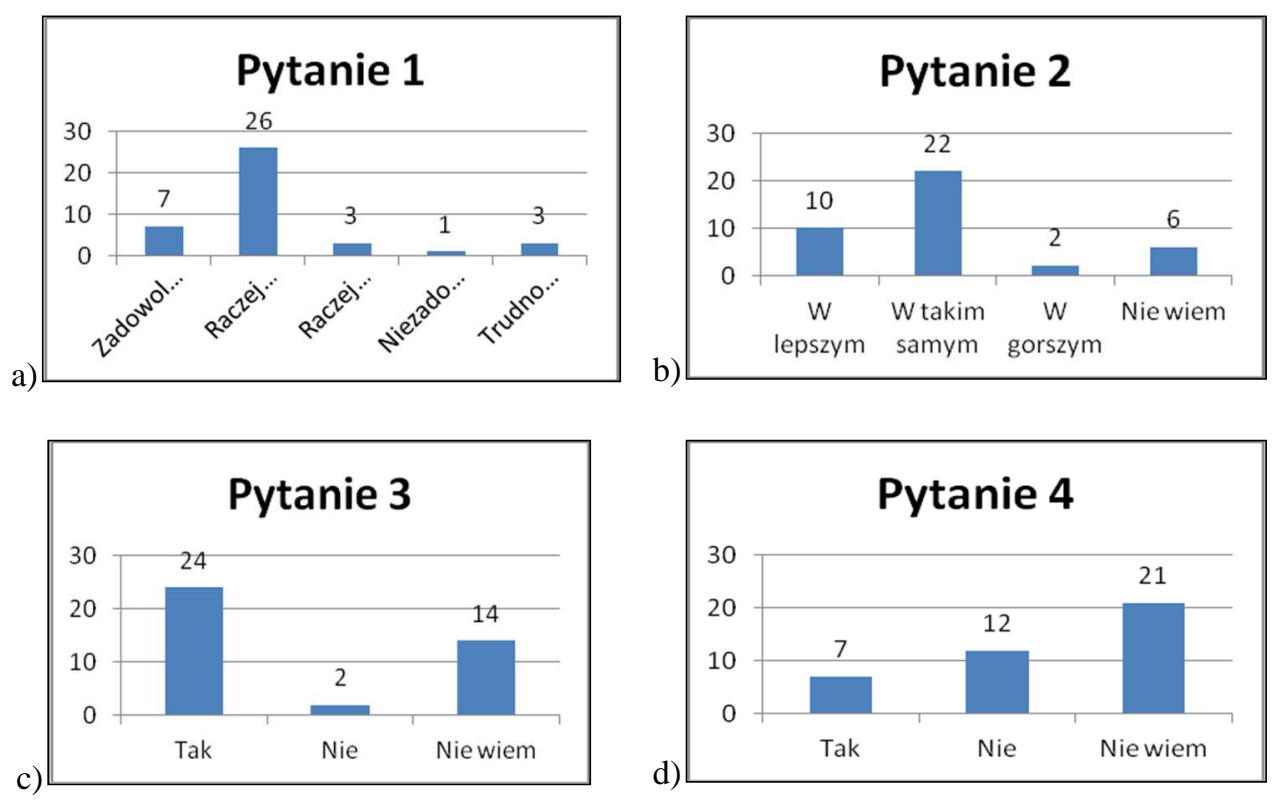



Rys. 13. Zestawienie wyników ankiety: a) pytanie 1 ; b) pytanie 2 ; c) pytanie 3 ; d) pytanie 4 ; e) pytanie 5 ; f) pytanie $6 ;$ g) pytanie 7

Fig. 13. Summary of the survey results: a) question 1 ; b) question 2 ; c) question 3 ; d) question 4 ; e) question 5 ; f) question 6 ; g) question 7

Znaczącym faktem jest, że badani ocenili stan budynków na utrzymany w dobrym stanie (47\%) (Rys. 13c), porównując do innych części miasta w takim samym (44\%) (Rys. 13b), a nawet lepszym. Pytani uważali, że główną przyczyną tego jest reprezentacyjna funkcja ulicy oraz usytuowanie jej w ścisłym centrum miasta. Najlepiej zachowanymi obiektami wg ankietowanych były: kościoły, banki oraz liceum. Na pytanie o budynki w złym stanie głosy ankietowanych były podzielone (Rys. 13d), ale najczęściej wskazywane obiekty to: budynek obok apteki na skrzyżowaniu z ul. Jagiellońską, kamienica Tekielskiego oraz dawne kino „Apollo”. Na pytanie, czy istnieje na ulicy zabytek, który można by uznać za symbol tej ulicy ankietowani w $48 \%$ odpowiadali, że „tak” (Rys. 13e). Najczęściej uznawane były: kościół p.w. Św. Krzyża, kościół farny oraz I LO.

Ponadto badani mieli podzielone głosy na temat działań podejmowanych w celu ochrony zabytków. Uważali, że robi się „raczej dużo” (36\%) lub „raczej mało" (22\%), aby chronić zabytkowe zabudowania (Rys. 13f). Wśród największych potrzeb miasta w przypadku ul. 3 Maja za najważniejsze uznano: ochronę zabytków (52\%) (Rys. 13g), organizowanie imprez kulturalnych (48\%) (Rys. $13 \mathrm{~g}$ ) oraz tworzenie nowych miejsc pracy (36\%) (Rys. 13g). Z odpowiedzi tych 
wynika, że młodzi ludzie cenią sobie kulturę i dziedzictwo miasta, w którym mieszkają lub przebywają. Badani, pomimo młodego wieku, są za utrzymaniem należytego stanu zabytków, co świadczy o wysokim statusie społecznym.

Niestety wśród ankietowanych zdarzały się osoby niezorientowane w temacie, bowiem za najlepiej zachowany obiekt uważały Ratusz, który nie jest zlokalizowany przy omawianej ulicy.

\section{Podsumowanie i wnioski końcowe}

Na przełomie XIX i XX w. ulica 3 Maja była głównym miejscem spotkań oraz źródłem najnowszych wiadomości z miasta. Obecnie rolę tę przejął Rynek. Pomimo tego, że ulica stawała się atrakcyjniejsza architektonicznie w wyniku odświeżania wyglądu elewacji kolejnych kamienic to zmieniała swoją funkcję poprzez wynajem lokali w budynkach pod usługi. Miasto powinno bardziej zadbać nie tylko o remonty kamienic, ale przede wszystkim o ograniczenie ruchu pojazdów samochodowych i zakaz wieszania niepotrzebnych reklam na budynkach. Najlepszym rozwiązaniem jest utworzenie parku kulturowego poprzez podjęcie stosownej uchwały przez radę miasta, zgodnie z ustawami: o ochronie zabytków i opiece nad zabytkami oraz o samorządzie gminnym. Sprawdzony przykład to działający Park Kulturowy Stare Miasto w Krakowie, utworzony na podstawie uchwały nr CXV/1547/10 Rady Miasta Krakowa z 3. 11. 2010 r.

Po przeprowadzonych badaniach dostrzegamy postawę młodych ludzi, dla których ważne jest dbanie o wygląd ulicy i zachowanie zabytków. Na podstawie licznych stron i forów internetowych można zauważyć zainteresowanie mieszkańców wyglądem Rzeszowa oraz aktywny udział w dyskusjach na temat dalszego rozwoju miasta. Sentyment i przywiązanie do niektórych miejsc dotyczy nie tylko osób starszych, ale też tych, którzy znają dawny Rzeszów tylko z opowieści i fotografii. W rozmowach dominują niestety negatywne opinie na temat ulicy. Głównie ze względu na funkcje znajdujących się tu budynków, remontowanie kamienic na jeden styl oraz zbyt częstą, jak na funkcję deptaka obecność pojazdów. Zatem możemy wywnioskować, że należy dążyć do przywrócenia pierwotnego przeznaczenia ulicy.

Na podstawie analizy wybranych kamienic na 3 Maja można zauważyć skłonności do ujednolicania wyglądu budynków poprzez stosowanie ciepłych pasteli na elewacjach oraz boniowania na parterach. Coraz częściej obserwuje się zjawisko udawania zabytkowości, co skutkuje nijakością. Dzieje się tak nie tylko na wskazanej przez nas ulicy, ale również w innych częściach miasta Rzeszowa.

\section{Bibliografia}

[1] http://www.fotogaleria.erzeszow.pl

[2] borowik.blox.pl 
[3] F. Kotula, „Tamten Rzeszów”, Rzeszów 1997.

[4] http://rzeszow.naszemiasto.pl

[5] Dokumentacja z Wojewódzkiego Urzędu Ochrony Zabytków na ul. Mickiewicza w Rzeszowie.

[6] Dokumentacja fotograficzna własna.

[7] http://m.rzeszow.gazeta.pl/

[8] http://mojepodkarpacie.pl/

[9] http://www.skyscrapercity.com/

[10] Opis techniczny do projektu budowlanego ,Zmiana sposobu użytkowania poddasza nieużytkowego na mieszkanie. Rzeszów, ul 3 Maja 3. dz nr 958, obr. 207”.

[11] M. Gosztyła, ,Przemiany idei i metod konserwatorskich w latach 1863-2003: na przykładzie zabytków architektury województwa podkarpackiego", Oficyna Wydawnicza Politechniki Rzeszowskiej, Rzeszów 2006.

\section{CONTROVERSY ABOUT THE FRONTAGE OF 3RD MAY STREET IN RZESZOW - OVERVIEW OF THE SELECTED TENEMENT HOUSES}

\section{S u m m a r y}

The aim of the article was to assess the historical and artistic value of selected buildings along the 3rd May Street in Rzeszow. The history of the street was presented and change of its meaning for over 300 years was discussed. More precisely in terms of design, the subsequent reconstructions and their functions were described the tenement houses No. 3, 13 and 20, which according to authors of the article changed the most. The field research was conducted and photographic documentation was made. The current state of the discussed tenements have been assessed in terms of architecture and culture. These examples may refer to the general trends in today Polish architecture, which are controversial in authors' opinion.

Also a survey on the interest of the protection of monuments located along the 3rd May Street for students and doctoral students of Rzeszów University of Technology was conducted. Results have been presented in charts and discussed.

Keywords: $3^{\text {rd }}$ May Street in Rzeszow, architecture of Rzeszow, tenement houses of Rzeszow

DOI: $10.7862 / \mathrm{rb} .2016 .289$

Przestano do redakcji: $30.06 .2016 r$.

Przyjęto do druku: 20.12.2016 r. 